\title{
Financial Distress Analysis Using Altman Z-Score Model In Sharia Banking In Indonesia
}

\section{Firman Setiawan ${ }^{1^{*}}$}

${ }^{1}$ Department of Islamic Economics, Faculty of Islamic Studies, Universitas Trunojoyo Madura, Indonesia

\begin{tabular}{l}
\hline \multicolumn{1}{c}{ ARTICLE INFO } \\
\hline Article history: \\
Received March 8, 2021 \\
Revised September 13, 2021 \\
Accepted September 27, 2021 \\
Available online October 1, 2021 \\
\hline Keywords: \\
financial distress, sharia banking, \\
altman z- score.
\end{tabular}

Paper type: Research paper

Please cite this article [Turabian of style 8th edition]: Setiawan, Firman.

" Financial Distress Analysis Using Altman Z-Score Model In Sharia Banking

In

Indonesia" IQTISHODUNA: Jurnal Ekonomi Islam [Online], Volume 10

Number 2 (1 October 2021)

\begin{abstract}
This study is conducted to explain the risk of financial failure that may occur in Sharia banking which is known asfinancial distress. Quantitative data in the formof financial ratios fromseveral Islamic banks which are the object of the study were analyzed using Altman Z- score model. After analyzing it, it is known that at Bank BRI Syariah Inc, the company experienced financial distress in 2015, in the following year the company experienced improvementthus in 2016-2019, the company was in good health. Bank BTPN Syariah Inc in 2015-2019 was in a good condition, which means that there was no financial distress or was in a gray area position. Bank Syariah Mandiri Inc experienced financial distress in 20152019, which means that during that time the company was in a gray area position
\end{abstract}

\footnotetext{
*Corresponding author

e-mail:

firman.setiawan@trunojoyo.ac.id Page: 105-122
}

IQTISHODUNA with CC BY license. Copyright $\odot$ 2021, the author(s)

Abstrak: Penelitian ini dilakukan untuk menjelaskan risiko kegagalan keuangan yang mungkin terjadi pada perbankan syariah yang dikenal dengan financial distress. Data kuantitatif berupa rasio keuangan dari beberapa bank syariah yang menjadi objek penelitian dianalisis dengan menggunakan model Altman Z-score. Setelah dianalisa diketahui bahwa pada Bank BRI Syariah Inc perusahaan mengalami financial distress pada tahun 2015, pada tahun berikutnya perusahaan mengalami perbaikan sehingga pada tahun 2016-2019 perusahaan dalam keadaan sehat. Bank BTPN Syariah Inc pada tahun 2015-2019 dalam kondisi baik yang artinya tidak ada financial distress atau berada pada posisi grey area. Bank Syariah Mandiri Inc mengalami financial distress pada tahun 2015-2019 yang artinya selama ini perusahaan berada pada posisi grey area.

Kata kunci: kesulitan keuangan perbankan syariah, altman z-skor 


\section{INTRODUCTION}

Every business entity that is established, whether by an individual or an entity has objectives, one of which is maximization of profit. In order to maximize profits, the effort made by a business entity (for example a company) is to conduct intense competition, both in terms of product quality and production activities efficiency. The intense competition then encourages the company to continue to innovate and always strengthen the company's operations and fundamentals thusthe company is able to compete with other companies and the company does not experience failure.

Basically, innovation and efforts to strengthen the company's operations and fundamentals are not only intended to survive from the pressure of competition, but more than that, thus the company can continue to survive by minimizing management errors leading to the company's failure to run its operations. In the end, this failure also results in financial problems that may experience the same failure. ${ }^{1}$

Therefore, it can be said that the quality ofcompany's financial performance can be a barometer whether management has been carried out properly or not, thus the company's performance can

\footnotetext{
${ }^{1}$ I Made Sudana, Manajemen Keuangan Teori Dan Praktik (Surabaya: Airlangga University Press, 2009).
}

continue to improve or contrary. Then one of ways to measure and assess the condition of a company is to analyze its financial performance. $^{2}$

The financial performance is a system that can describe the condition and economic performance of a company through a variety of strategies and efforts taken, including the profit obtaine din short term or long term. ${ }^{3}$

To find out the financial performance, it is necessary to analyze and measure the company's financial system, one of which is financial distress analysis, which is a condition in which financial performance begins to decline and it becomes a sign that the company is moving towards bankruptcy. The need to analyze financial distress is to determine the condition of a company as early as possible thus preventive measures can be taken to anticipate company bankruptcy which is generally caused by decreased financial performance which then impacts on business failure. ${ }^{4}$

2 S Munawir, Analisis Informasi Keuangan, 1st ed. (Yogyakarta: Liberty Yogyakarta, 2002).

3 Riswan Riswan and Yolanda Fatrecia Kesuma, "Analisis Laporan Keuangan Sebagai Dasar Dalam Penilaian Kinerja Keuangan PT. Budi Satria Wahana Motor," Jurnal Akuntansi dan Keuangan 5, no. 1 (March 31, 2014), accessed August 13, 2020, http://jurnal.ubl.ac.id/index.php/jak/arti cle/view/449.

4 Ahmad Radoni and Herni Ali, Manajemen Keuangan Modern (Jakarta: Mitra Wacana Media, 2014). 
Adverse effect of business failure such as bankruptcy will be felt by all people, which is one of it is the occurrence of work termination. It will result in the number of unemployed and the poverty rate increasing. Therefore, every company is required to always maintain the stability of its business, in terms of operations and company finances. So the need to know the potential failure of a company by conducting financial distress analysis is to make the company can find out the financial risks that may be faced and immediately take steps to prevent these risks to occur. This is intended to make the company does not experience stages of difficulty or even financial failure, such as bankruptcy or the company being liquidated. ${ }^{5}$

Financial distresscan be an "early warning" as a warning that there are problems at the company that need to be fixed. Generally, companies with relatively high liabilities will experience financial distress more quickly than companies with relatively low amounts of liabilities. Therefore, companies that are aware of financial distress earlier should have more time to improve their company operations than those that realize it too late. ${ }^{6}$

\footnotetext{
${ }^{5}$ Brealey, Myers, and Marcus, Dasar-Dasar Manajemen Keuangan Perusahaan, 5th ed. (Jakarta: Erlangga, 2006).

6 Radoni and Ali, Manajemen Keuangan Modern.
}

There are many formulas developed and used by economists in the world to analyze performance and predict the risk of failure, howeverAltman Z- Score is the formula which is mostly used. Edward I. Altman is the first person introducing this model through his book, "Corporate Financial distress: A Complete Guide to Predicting, Avoiding, and Dealing with Bankruptcy." This formula can be used to detect and predict the risk of financial difficulties and even business failure that a company may experience by calculating several financial ratio values in the discriminant equation. ${ }^{7}$

Altman then adapted and developed this model in 1968 with the name Altman Z- score to determine a financial failure rate. According to many experts, this model has a higher degree of accuracy than other models. Even tests conducted on several US companies, the level of accuracy reached $95 \%$ before the company went bankrupt. To get more accurate prediction result, Altman took several samples from different economic conditions which are expected to improve the model. ${ }^{8}$

As explained above, the accuracy of the analysis using Altman Z- score model is quite high, because regardless of the size of a company, if the results of the $z$ -

\footnotetext{
7 Irham Fahmi, Manajemen Keuangan Perusahaan Dan Pasar Modal (Jakarta: Mitra Wacana Media, 2014).

${ }^{8}$ Munawir, Analisis Informasi Keuangan.
} 
score calculation are not good enough, the company must be prepared to face financial risks that may occur even though the company looks like in a good state. The existence of this analysis does not determine whether the company is bankrupt, but this analysis serves as a warning to the company thus it can anticipate the worst that will come. ${ }^{9}$

Practically, the development of some companies may not always be as good as planned. Moreover, companies that are already considered financially, operationally and in management are wellestablished sometimes still experience financial difficulties which can result in failure. This failure does not happen with only one type of a particular industry, but also can be experienced by all types of industries and companies, both manufacturers and financial institutions. Therefore, the banking industry is one of the sectors that also has the potential to experience financial distress.

As happened during the 1998 crisis which resulted in at least 64 banks in the period of 1997-1999 experiencing financial difficulties which resulted in regulators had to take rescue steps, including liquidating several banks, freezing

\footnotetext{
9 Riska Natariasari and Nofiandre, "Analisis Prediksi Kebangkrutan Menggunakan Model Z-Score Altman pada Perusahaan Perbankan Yang Terdaftar di Bursa Efek Indonesia Periode 2008-2010," Jurnal Sosial Ekonomi Pembangunan 10 (2013): 23.
}

bank business activities, merging several banks, stopping operations, expropriation, and recapitalization. ${ }^{10}$

Conversely, Sharia banking is considered to have better performance when facing the pressure of the crisis. When conventional banks experience a negative spread, Islamic banks or Sharia Banks actually show good conditions. This is because theoretically, Sharia banks have stabilization and efficiency tools which are commonly referred to as profit and loss sharing. When Sharia banks are depressed and their income decreases, the liabilities of it also decrease, thus the decrease in income does not significantly affect the level of liquidity of Sharia banks. ${ }^{11}$

10 Abdul Ghofur Anshori, Perbankan Syariah Di Indonesia (Yogyakarta: UGM Press, 2018); Imaduddin Shidiq and Buddi Wibowo, "Prediksi Financial Distress Bank Umum di Indonesia: Analisis Diskriminan dan Regresi Logistik," ESENSI: Jurnal Bisnis dan Manajemen 7, no. 1 (February 4, 2017): 27-40.

11 Salman Syed Ali, Financial Distress and Bank Failure: Lessons from Closure of Ihlas Finans in Turkey, SSRN Scholarly Paper (Rochester, NY: Social Science Research Network, January 1, 2007), accessed August 25 , 2020, https: / / papers.ssrn.com/abstract=3161383; Rendra Pratama, "Analisis Pengaruh Rasio Keuangan Untuk Memprediksi Kondisi Financial Distress Bank Umum Syariah Menggunakan Model Logit Di Indonesia" (undergraduate, STIE PERBANAS SURABAYA, 2016), accessed August 15, 2020, http:/ / eprints.perbanas.ac.id/528/. 
However, the fact in some countries is that Islamic banks are not always able to get out of financial difficulties. Some of them are proven to show symptoms of financial distress, and are even threatened with failure. Apart from the pressure of the macroeconomic crisis, it can be also caused by several things, such as internal bank problems, the banking environment, regulatory factors and customer behavior. ${ }^{12}$

Not only in other countries, in Indonesia there are also several Sharia banks that have the potential to experience financial problems. As the results of research conducted recently, that in the period of 20102016, there were two out of ten Sharia banks that were in the gray area that is in doubtful conditions or had the potential to experience financial distress. ${ }^{13}$

Therefore, in fact not a single financial institution, both Sharia and conventional, is truly resilient in facing financial problems and difficulties. Including Sharia banks in Indonesia, which, when viewed from the number of assets, are still quite far behind from conventional banks.

Based on the above explanation, it can be said that

\footnotetext{
12 Ali, Financial Distress and Bank Failure.

13 Muhammad Ilham, "Analisis Potensi Financial Distress Pada Bank Syariah Di Indonesia Pasca Krisis Global Periode Tahun 2010 - 2016" (May 11, 2018), accessed August 25, 2020, https://dspace.uii.ac.id/handle/123456789 /7872.
}

financial distress analysis as a preventive measure to avoid financial problems in financial institutions, especially Sharia banking, must be carried out in a sustainable manner.

Therefore, it is quite important according to the writer, to continuously and sustainably conduct studies on the condition of Sharia banks, especially financially, with the model formulated by Altman.

The use of this Altman analysis tool is because based on several research results, which stated that this model is quite accurate in predicting the risk of corporate financial distress (including banking) in most countries, with an accuracy rate of around $75 \% .{ }^{14}$

\section{Financial Distress}

According to Altman, financial distress is a company's inability to complete its obligations. This is due to the condition of the company's assets, which were

14 Edward I. Altman et al., "Financial Distress Prediction in an International Context: A Review and Empirical Analysis of Altman's Z-Score Model," Journal of International Financial Management $\mathcal{E}$ Accounting 28, no. 2 (2017): 131-171; George M. Holmes, Brystana G. Kaufman, and George H. Pink, "Predicting Financial Distress and Closure in Rural Hospitals," The Journal of Rural Health 33, no. 3 (2017): 239-249; Martin Bod'a and Vladimír Úradníček, "The Portability of Altman's ZScore Model to Predicting Corporate Financial Distress of Slovak Companies," Technological and Economic Development of Economy 22, no. 4 (July 3, 2016): 532-553. 
initially available, then the value becomes smaller than the value of the liabilities thus it is not possible to cover it. There are two things that can be understood from this definition.They are stock and flow, both of which indicate the company's inability to cover its liabilities (debt). Stock-based insolvency is a condition in which the company's net worth is negative and the asset value is smaller than the total liabilities. Meanwhile flow based insolvency is the company's inability to pay debts. ${ }^{15}$

The potential offinancial distress can be experienced by a company if for more than one year it does not provide dividends to shareholders, even though it has already benefited for several years. Likewise when company gain profit and successively value of equity book is in a negative position and experience delisted. ${ }^{16}$

Financial distressbegins from the condition of a company that is no longer able to fulfill its obligations, both short-term liabilities, including those related to the availability of current assets to carry out its operational activities, as well as long-term liabilities. ${ }^{17}$

15 Radoni and Ali, Manajemen Keuangan Modern, 186.

16 Ibid.

17 Anggi Meiliawati and Isharijadi Isharijadi, "Analisis Perbandingan Model Springate Dan Altman Z Score Terhadap Potensi Financial Distress (Studi Kasus Pada Perusahaan Sektor Kosmetik Yang Terdaftar Di Bursa Efek Indonesia)," Assets: Jurnal Akuntansi dan Pendidikan 5, no. 1 (April 25, 2017): 15-24.
With that explanation, it is understood that the conditions of the weakening of company's financial aspects to be the reason for his inability to settle the obligation is called as financial distress. Detecting financial distress is the first step for the company to clean up and make improvements thus the damage does not get worse, which eventually leads to bankruptcy.

Financial distressin a company can be caused by several factors, they are: 18

a. Economic aspects, it happens because the company runs a bad business model, the company is run with an inefficient management system, and the company's capital base is not ideal. In a certain period, there is a decrease in the level of consumption thus the consumers diminish, which results in lower income earned.

b. Financial aspects or company funding. For small companies with very limited capital, the

18 Josua Tarigan, Swenjiadi Yenewan, and Grace Natalia, Merger Dan Akuisisi: Perspektif Strategis Dan Kondisi Indonesia (Yogyakarta: Ekuilibria, 2017), 104-107; Nur Fadli Andriawan and Dantje Salean, "Analisis Metode Altman Z-Score Sebagai Alat Prediksi Kebangkrutan Dan Pengaruhnya Terhadap Harga Saham Pada Perusahaan Farmasi Yang Terdaftar Di Bursa Efek Indonesia," JEA17: Jurnal Ekonomi Akuntansi 1, no. 01 (April 8, 2016), accessed October 1, 2020, http://jurnal.untagsby.ac.id/index.php/JEA17/article/view/ 650. 
main problem faced in general is the problem of funding. To solve this problem, sometimes companies try to get loans. However, when the company then experiences financial problems, and is unable to run its operations, capital owners are sometimes reluctant to provide additional debt so that this situation will be worst, which in the end could risk bankruptcy.

c. Governance factor. Poor management and governance will make the company being unable to carry out all activities efficiently. Therefore, experience, knowledge and skills of a manager in runningand managing the company are absolutely necessary thus financial failures and difficulties can be avoided. The lack of experience, knowledge and skills of a manager can increase the tendency of bad decision making and the risk of financial distress.

d. Fraud factor. Fraud is included as one that can result in the company experiencing difficulties and financial failure. Intentional cheating done by someone for its own sake or one of the parties is called fraud.

In general, there are four types or categories of financial distress that may occur in a company, they are:19

e. Category A. It is a condition in which the company experiences

19 Fahmi, Manajemen Keuangan Perusahaan Dan Pasar Modal, 161-162. financial failure which has entered a dangerous stage. In this condition, the company can be declared bankrupt. This category includes financial distress which is very high.

f. Category B. In this category, the company situation is quite dangerous. However, it still cannot be declared as bankrupt. Companies can do several things to survive this kind of situation, including selling several sets of companies that are deemed feasible to sell, conducting mergers, acquisitions (takeovers), or even laying off several employees. This category includes high financial distress.

g. Category C. If the company in this condition, the company faces financial difficulties but it is still considered capable of saving itself. Providing additional funds is an effort that can be done, whether the funds come from internal or external sources. Apart from improving financial condition, it is also necessary to make improvements in policies and running management system, as well as recruiting new workers who are having competence in the field and can be expected to assist in efforts to rescue the company. This category includes as moderate financial distress.

h. Category D. In this state, the company is experiencing financial difficulties, but it is regarded as a state that occurs temporarily. Usually this 
category occurs because of inappropriate decisions by several parties. This category is short term, so this category can be addressed immediately. Among the efforts to repair that can be taken is by increasing liquidity, both from company reserves or from external sources. This category is included as low financial distress.

\section{RESOLUTIONS \\ COMPANY FAILURES} OF

If a company faces financial difficulties, it is necessary to know in advance whether the problem is related to short-term or long-term debt. If the cause is short-term debt, the company must immediately improve its performance thus there will be no financial difficulties are more severe. Company liquidation is a short-term financial problem, while when it is related to the company's solvency, it is said that the company is experiencing long-term financial difficulties. Here are some ways that are usually done to overcome financial difficulties: 20

a. Voluntarysettlements

This method is known as voluntary settlement, where the parties (creditors and debtors) agree to solve the problem by finding the best way. In this case, there

20 Sudana, Manajemen Keuangan Teori Dan Praktik, 250. are three possible things to do, they are:

1) Extension

It is when creditors and debtors agree to providean extension of thematurity date. This is intended to make liquidity, which was originally allocated to pay debts, can be used to finance operation all activities so that the company's financial condition is expected to rise.

2) Composition

This method can be done with the creditors' willingness to free the part of the debtor's debt. Or it could be by changing the contract that was originally a debt to equity so that the debtor's burden to pay interest and principal is easier.

3) Liquidationbyvoluntary agreement

Creditors decide to liquidate voluntarily or informally. The advantage is that the liquidation process carried out by the company and creditors is faster, more efficient and the decrease in the value of the assets being liquidated can be minimized. 
b. Settlements involving litigation

This step is only taken if the previous method, that is making an agreement, cannot be achieved. Thus, this method is the last alternative that can be taken. One way out that is taken legally is liquidation. This is if the company is convincingly deemed unable to improve its financial condition again, so the court gives a decision that the company is declared bankrupt.

\section{Analysis of Altman Z-score Model}

There are several formulas that have been formulated by experts regarding this financial distress analysis. However, the formulation initiated and introduced by Altman or what is known as Altman Zscore is perhaps the most popular and the most frequently used. ${ }^{21 Z}$ - score is the value of the calculation offinancial ratios that can predict the like lihoodof a company's financial failure. Through this calculation and analysis, it can be seen whether a company is said to be financially in a good condition or not.

21 Fahmi, Manajemen Keuangan Perusahaan Dan Pasar Modal, 160.

\begin{abstract}
Altman has developed several formulas for calculating and measuring financial distress in several types of companies. Altman understands that every company with a different type of business, its financial calculation criteria will also be different. So Altman then offers three different formulas based on the type of company. The three formulas which are used are:22
\end{abstract}

a. The First Altman Model

This model can be used in financial analysis and bankruptcy prediction in a manufacturing company that has gone public. The First Altman Model uses the formula: $Z=1,2 X 1+1,4 \times 2+3,3 \times 3+0,6$ $\mathrm{X} 4+1,05$ X5

Information:

$\mathrm{X} 1=$ Working capital to Total asset

$\mathrm{X} 2=$ Retaine dearnings to Total asset

$\mathrm{X} 3$ = Earnings before interes tand taxes (EBIT) to Total asset

X4 = Market value of equity to Book value of debt

X5 $=$ Sales toTotal asset

In the above formula, scores are then classified into the following three categories:

\begin{tabular}{|l|l|}
\hline \multicolumn{1}{|c|}{$\begin{array}{l}\text { Z- } \\
\text { score }\end{array}$} & \multicolumn{1}{c|}{ Classification } \\
\hline $\begin{array}{l}Z>2,9 \\
9\end{array}$ & Healthy \\
\hline
\end{tabular}

22 Kariyoto, Kariyoto, Manajemen Keuangan: Konsep Dan Implementasi (Malang: Universitas Brawijaya Press, 2018), 228-229. 


\begin{tabular}{|l|l|}
\hline $\begin{array}{l}1,81< \\
Z<2,9 \\
9\end{array}$ & Grey area \\
\hline $\begin{array}{l}Z<1,8 \\
1\end{array}$ & Threatened bankruptc \\
\hline
\end{tabular}

Table1.1 Classification of the First Altman Model

b. Revised Altman Model

This model is a revision and development of the previous version, where this model is considered to be more appropriate to be used in manufacturing companies, especially those that have offered their shares in the market. But apart from that, private companies generally also use this model. Revised Altman Model uses this formula:

$Z^{\prime}=0,717 X 1+0,847 X 2+3,107$ $X 3+0,42 X 4+0,998 X 5$

Information:

$\mathrm{X} 1=$ Working capital to total asset

$\mathrm{X} 2=$ Retainedearnings tototal asset

$\mathrm{X} 3=$ Earnings before interest and tax to total asset

$\mathrm{X} 4=$ Book value of equity to book value of total debt

X5 $=$ Sales to total asset

Revised Altman Model Z-scoreis classified into three following classification:

\begin{tabular}{|l|l|}
\hline \multicolumn{1}{|c|}{ Z-score } & \multicolumn{1}{c|}{ Classification } \\
\hline$Z>2,99$ & Healthy \\
\hline $1,23<Z^{\prime}<2,9$ & Grey Area \\
\hline$Z^{\prime}<1,23$ & $\begin{array}{l}\text { Threatened } \\
\text { bankruptcy }\end{array}$ \\
\hline
\end{tabular}

Table1.2 Classification of Revised Altman Model c. Modified Altman Model

It is generally more appropriate for nonmanufacturing companies to use this model. This is because the $\mathrm{X} 5$ variable is not used in this model, that is the ratio of sales to total assets (sales to total assets), which is considered to have little effect. Of course, this is different from the manufacturing company where the ratio of sales to total assets has an influence in the calculation of financial distress.

Modified Altman Model

uses this formula:

$Z^{\prime \prime}=6,56 \mathrm{X} 1+3,26 \mathrm{X} 2+6,72 \times 3$

$+1,05 \times 4$

Information:

$\mathrm{X} 1=$ Workingcapitalto total asset

$\mathrm{X} 2=$ Retainedearnings to total asset

$\mathrm{X} 3=$ Earnings before interest and tax to total asset

$\mathrm{X} 4$ = Book value of equity to book value of total debt

This model is categorized into the three following category:

\begin{tabular}{|l|l|}
\hline \multicolumn{1}{|c|}{ Z-score } & \multicolumn{2}{c|}{ Classification } \\
\hline$Z^{\prime \prime}>2,6$ & Healthy \\
\hline $1,1<Z^{\prime \prime}<2,6$ & Grey area \\
\hline$Z^{\prime \prime}<1,1$ & $\begin{array}{l}\text { Threatened } \\
\text { bankruptcy }\end{array}$ \\
\hline & Table1.3 Classification of
\end{tabular}

Modified Altman Model.

\section{Altman Z- score Model Components}

There are five types of financial ratios used in the 
formulation of this model to determine whether a company is said to be healthy, in grey zone, or is threatened with bankruptcy. The five financial ratios are as follows: ${ }^{23}$

a. Working Capital to Total Assets

It is the financial ratio used to measure how much the company produces net working capital from total assets owned. This ratio is calculated by dividing net working capital by total assets. The company will experience financial problems if the net working capital is negative, especially to cover short-term debt. Conversely, companies whose net working capital is positive will tend to be safe from financial problems.

b. RetainedEarnings to Total Assets

This ratio is to measure how well a company is able to generate retained earnings from its total assets. This ratio can also describe the age of a company, because companies that are young or newly established have less time to build cumulative profits. On the other hand, companies that are older or have been established for a long time will benefit more, because it is normal for younger companies to give a high failure rate. If the company starts to lose money, of course the retained earnings and $\mathrm{X} 2$ ratio will be negative.

23 Sri Suartini and dkk, Analisis Laporan Keuangan Bagi Mahasiswa Dan Praktikan (Jakarta: Mitra Wacana Media, 2017), 163164. c. Earnings BeforeInterestandTaxesto Total Assets

With this ratio, the company can find out its ability to earn profit from operational activities before tax and interest costs are incurred. How to calculate it is by dividing income before taxes and interest by the total assets of the company. The company is considered capable of earning an income higher than the interest that must be paid if the value of the calculation result is greater than the average interest rate paid.

d. Market Value of Equity to Book Value of Debt $\mathcal{E}$ BookValue Equity to Book Value of Debt

This ratio is to find out whether the market value of a company's own capital is sufficient to cover its liabilities. The method of calculating the capital market value itself is the share price per share multiplied by the number of ordinary shares outstanding. Meanwhile, the book value of debt can be seen from the sum of current liabilities and long-term liabilities. In general, the company will fail if it has its own capital less than its accumulated debt.

The ratioof book value equity to book value of debt is to measure the level of decline in the value of assets owned and is used to guarantee the company's debt.

e. Salesto Total Assets 
It is financial ratio that shows how well the company increased its sales of assets owned. So it can be said that this ratio is to describe how capable management is to compete with other companies in the same market. This ratio reflects the efficiency of management in optimizing the use of all assets owned to increase sales and generate profits.

\section{METHODS}

This research is a descriptive quantitative study with a model formulated by Altman (Altman ZScore) as an analysis tool. In this study, there are two variables used, they are the response variable and the explanatory variable. The response variable in this study is the financial ratios in Altman Z- score model while the explanatory variable is the calculated score from Altman Z- score model.

The results of this analysis / calculation will be adjusted to the limits and classification previously described to determine whether the company under study is a healthy company, gray area or is threatened with bankruptcy.

Data in the form of financial ratios from several companies / Sharia Banks which were the object of the study were used as material for analysis. These data are to show the value of the variables used in this study. This data is a combination of two types of data: they aretime series data and cross sectional data.

This financial ratio data is obtained from financial reports published by Sharia companies / banks which are the object of the research. Therefore, the data collected by researcher is secondary data.

The technique of collecting data is to use documentation study using online research to collect data in the form of annual financial reports published by the company.

The object of this research is Sharia banking in Indonesia, registered with the Financial Services Authority (OJK), and has published financial reports in 20152019.

Sharia banks in Indonesia that fall into these criteria are as follows:

\begin{tabular}{|c|c|}
\hline No. & Name of Bank \\
\hline 1. & Bank BRI Syariah Inc \\
\hline 2. & Bank BTPN Syariah Inc \\
\hline 3. & $\begin{array}{l}\text { Bank Mandiri Syariah } \\
\text { Inc }\end{array}$ \\
\hline \multicolumn{2}{|c|}{$\begin{array}{c}\text { Table } 3.1 \\
\text { SamplesofShariaCommercia } \\
1 \text { Bank Companies in } \\
\text { Indonesia }\end{array}$} \\
\hline
\end{tabular}

The analysis conducted by the researcher is a discriminant analysis. The data collected then are then changed into the equation of Altman Z-score according to the type and designationthat isModified Altman Model. The formulas 
and variables used are as described above.

\section{RESULTS and ANALYSIS \\ Results of Data Analysis}

\section{Bank BRIsyariah Inc}

At Bank BRIsyariah Inc, it is known that the calculated value in 2015 was in financial distress or it can be said that the company was in a gray area because the $z$ - score was in the position of 1.1 to 2,6 $\left(1,1<Z^{\prime \prime}<2,6\right)$. In 2015 the $\mathrm{z}$ score was 2.4533. In the following years that are 20162019 , the company experienced a healthy condition with $\mathrm{z}$ - score of more than 2.6 ( $Z>2.6)$. In 2016 the $z$ - score was 2,6114 with a healthy condition. In 2017, the zscore was 2.8715 with a healthy condition. In 2018 the $\mathrm{z}$ - score was 3.1281 with a healthy condition. And in 2019 the zscore was 2.8189 with a healthy company condition. When viewed from the $z$ - score value, the company experienced an increase in the 2016-2018 zscore. But in 2019, the $\mathrm{z}$ - score fell again. That way the company needs to be careful not to return to the gray area so as to avoid the possibility of experiencing bankruptcy. The following is a calculation using the Altman analysis at Bank BRIsyariah Inc.

\section{Table 2.1}

\section{Altman Z- score analysis at Bank BRIsyariah Inc in}

2015-2019Period

\begin{tabular}{|c|c|c|c|c|c|}
\hline $\begin{array}{l}\text { Vari } \\
\text { able }\end{array}$ & $\begin{array}{c}201 \\
5\end{array}$ & $\begin{array}{c}201 \\
6\end{array}$ & $\begin{array}{c}201 \\
7\end{array}$ & $\begin{array}{c}201 \\
8\end{array}$ & $\begin{array}{c}201 \\
9\end{array}$ \\
\hline $\begin{array}{c}\mathrm{X} 1= \\
\mathrm{WC} / \\
\mathrm{TA}\end{array}$ & $\begin{array}{c}0,3 \\
017\end{array}$ & $\begin{array}{c}0,3 \\
324\end{array}$ & $\begin{array}{c}0,3 \\
783\end{array}$ & $\begin{array}{l}0,4 \\
035\end{array}$ & $\begin{array}{c}0,3 \\
566\end{array}$ \\
\hline $\begin{array}{c}\mathrm{X} 2= \\
\mathrm{RE} / \\
\mathrm{TA}\end{array}$ & $\begin{array}{c}0,0 \\
144\end{array}$ & $\begin{array}{c}0,0 \\
187\end{array}$ & $\begin{array}{c}0,0 \\
183\end{array}$ & $\begin{array}{l}0,0 \\
028\end{array}$ & $\begin{array}{l}0,0 \\
036\end{array}$ \\
\hline $\begin{array}{c}\mathrm{X} 3= \\
\mathrm{EBIT} \\
/ \mathrm{TA}\end{array}$ & $\begin{array}{c}0,0 \\
065\end{array}$ & $\begin{array}{c}0,0 \\
086\end{array}$ & $\begin{array}{l}0,0 \\
044\end{array}$ & $\begin{array}{l}0,0 \\
041\end{array}$ & $\begin{array}{l}0,0 \\
027\end{array}$ \\
\hline $\begin{array}{c}\mathrm{X} 4= \\
\mathrm{BE} / \\
\mathrm{BVD}\end{array}$ & $\begin{array}{l}0,3 \\
643\end{array}$ & $\begin{array}{l}0,2 \\
965\end{array}$ & $\begin{array}{l}0,2 \\
860\end{array}$ & $\begin{array}{l}0,4 \\
225\end{array}$ & $\begin{array}{l}0,4 \\
282\end{array}$ \\
\hline $\begin{array}{c}6,56 \\
X 1\end{array}$ & $\begin{array}{l}1,9 \\
796\end{array}$ & $\begin{array}{c}2,0 \\
180\end{array}$ & $\begin{array}{l}2,4 \\
818\end{array}$ & $\begin{array}{l}2,6 \\
473\end{array}$ & $\begin{array}{l}2,3 \\
387\end{array}$ \\
\hline $\begin{array}{c}3,26 \\
x 2\end{array}$ & $\begin{array}{l}0,0 \\
469\end{array}$ & $\begin{array}{l}0,0 \\
611\end{array}$ & $\begin{array}{c}0,0 \\
596\end{array}$ & $\begin{array}{c}0,0 \\
091\end{array}$ & $\begin{array}{c}0,0 \\
120\end{array}$ \\
\hline $\begin{array}{c}6,72 \\
X 3\end{array}$ & $\begin{array}{l}0,0 \\
440\end{array}$ & $\begin{array}{c}0,0 \\
580\end{array}$ & $\begin{array}{l}0,0 \\
297\end{array}$ & $\begin{array}{l}0,0 \\
279\end{array}$ & $\begin{array}{l}0,0 \\
184\end{array}$ \\
\hline $\begin{array}{c}1,05 \\
X 4\end{array}$ & $\begin{array}{l}0,3 \\
825\end{array}$ & $\begin{array}{c}0,3 \\
113\end{array}$ & $\begin{array}{c}0,3 \\
003\end{array}$ & $\begin{array}{l}0,4 \\
437\end{array}$ & $\begin{array}{l}0,4 \\
496\end{array}$ \\
\hline $\begin{array}{c}\text { Z- } \\
\text { scor } \\
\text { e }\end{array}$ & $\begin{array}{c}2,4 \\
533\end{array}$ & $\begin{array}{c}2,6 \\
114\end{array}$ & $\begin{array}{l}2,8 \\
715\end{array}$ & $\begin{array}{c}3,2 \\
181\end{array}$ & $\begin{array}{c}2,8 \\
18\end{array}$ \\
\hline
\end{tabular}

2. Bank BTPN Syariah Inc

At Bank BTPN Syariah Inc, it is known that the calculated value for 2015-2019 was in a healthy condition or did not experience financial distress because the $\mathrm{z}$ - score was more than 2.6 ( $Z^{\prime \prime}>2.6$ ). In 2015, the $\mathrm{Z}-$ score was 3,2207 with a healthy company condition. In 2016 the z- score was 3.5885 with a healthy company condition. In 2017 the $\mathrm{z}$ - score was 4.2789 with a healthy company condition. In 2018 the z-score was 5.6796 with 
a healthy company condition. And in 2019 the $z$ - score was 6.9443 with a healthy condition. If we look at the $\mathrm{z}$ - score, which is getting further away from the gray area value, the company is showing better performance every year. The following is a calculation using Altman analysis at Bank BTPN Syariah Inc.

Table 4.2

Altman Z- score analysis atBank BTPN Syariah Inc in 2015-2019 Period

\begin{tabular}{|c|c|c|c|c|c|}
\hline $\begin{array}{l}\text { Vari } \\
\text { able }\end{array}$ & $\begin{array}{l}20 \\
15 \\
\end{array}$ & $\begin{array}{l}20 \\
16 \\
\end{array}$ & $\begin{array}{l}20 \\
17 \\
\end{array}$ & $\begin{array}{l}20 \\
18 \\
\end{array}$ & $\begin{array}{l}20 \\
19 \\
\end{array}$ \\
\hline $\mathrm{X} 1=$ & 0,2 & 0,2 & 0,2 & 0,3 & 0,3 \\
\hline WC & 23 & 31 & 98 & 45 & 90 \\
\hline /TA & 9 & 5 & 7 & 6 & 5 \\
\hline $\mathrm{X} 2=$ & 0,0 & 0,0 & 0,1 & 0,1 & 0,2 \\
\hline RE/ & 53 & 94 & 47 & 95 & 44 \\
\hline TA & 3 & 7 & 4 & 4 & 5 \\
\hline $\mathrm{X} 3=$ & 0,0 & 0,0 & 0,0 & 0,1 & 0,1 \\
\hline EBIT & 48 & 75 & 60 & 08 & 22 \\
\hline /TA & 1 & 7 & 5 & 1 & 2 \\
\hline$X 4=$ & 1,1 & 1,1 & 1,3 & 1,9 & 2,6 \\
\hline BE/ & 94 & 92 & 63 & 50 & 31 \\
\hline BVD & 3 & 2 & 2 & 2 & 5 \\
\hline 6,56 & 1,4 & 1,5 & 1,9 & 2,2 & 2,5 \\
\hline \multirow[t]{2}{*}{ X1 } & 68 & 18 & 59 & 67 & 62 \\
\hline & 8 & 6 & 6 & 7 & 3 \\
\hline 3,26 & 0,1 & 0,3 & 0,4 & 0,6 & 0,7 \\
\hline \multirow[t]{2}{*}{$X 2$} & 73 & 08 & 80 & 37 & 97 \\
\hline & 9 & 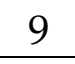 & 6 & 1 & 2 \\
\hline 6,72 & 0,3 & 0,5 & 0,4 & 0,7 & 0,8 \\
\hline \multirow[t]{2}{*}{ X3 } & 23 & 09 & 07 & 27 & 21 \\
\hline & 8 & 1 & 1 & 0 & 7 \\
\hline 1,05 & 1,2 & 1,2 & 1,4 & 2,0 & 2,7 \\
\hline \multirow[t]{2}{*}{ X4 } & 54 & 51 & 31 & 47 & 63 \\
\hline & 0 & 8 & 4 & 7 & 1 \\
\hline Z- & 3,2 & 3,5 & 4,2 & 5,6 & 6,9 \\
\hline
\end{tabular}

\begin{tabular}{|c|c|c|c|c|c|}
\hline $\begin{array}{c}\text { scor } \\
\text { e }\end{array}$ & 20 & 88 & 78 & 79 & 44 \\
\multicolumn{5}{c|}{ Source: Processed Data }
\end{tabular}

3. Bank Syariah Mandiri Inc

At Bank Syariah Mandiri Inc, it is known that the calculated value for 2015-2019 was in the gray area because the $\mathrm{z}$ - score is Between 1.1 - 2.6 (1.1 $\left.<Z^{\prime \prime}<2.6\right)$. In 2015 the $Z$ - score value was 1.6714 with the condition of the company in the gray area. In 2016 the z- score value was 1.9190 withthe condition of the company in the gray area. In 2017 the $\mathrm{z}$ - score value was 1.8824 with the condition of the company in the gray area. In 2018 the $\mathrm{z}$ - score value was 1.6052 with the condition of the company in the gray area. And in 2019 the zscore value is 1.6366 with the condition of the company in the gray area. When viewed from the $\mathrm{z}$ - score value, the company still has to be careful, in order to avoid the possibility of a more severe condition that is bankruptcy. The following is a calculation using Altman analysis at Bank Syariah Mandiri Inc.

Table 4.3

Altman Z- score analysis atBank Syariah Mandiri Inc in 2015-2019 Period

\begin{tabular}{|c|c|c|c|c|c|}
\hline $\begin{array}{c}\text { Varia } \\
\text { ble }\end{array}$ & $\begin{array}{c}\mathbf{2 0 1} \\
\mathbf{5}\end{array}$ & $\begin{array}{c}\mathbf{2 0 1} \\
\mathbf{6}\end{array}$ & $\mathbf{2 0 1}$ & $\mathbf{2 0 1}$ & $\mathbf{2 0 1}$ \\
\hline $\mathrm{X} 1=$ & 0,13 & 0,17 & 0,17 & 0,12 & 0,12 \\
$\mathrm{WC} /$ & 0,13 & $\mathbf{9}$ \\
$\mathrm{TA}$ & 55 & 31 & 27 & 41 & 95 \\
\hline $\mathrm{X} 2=$ & 0,04 & 0,04 & 0,04 & 0,04 & 0,05 \\
\hline
\end{tabular}




\begin{tabular}{|c|c|c|c|c|c|}
\hline $\begin{array}{c}\mathrm{RE} / \mathrm{T} \\
\mathrm{A}\end{array}$ & 60 & 52 & 47 & 61 & 17 \\
\hline $\begin{array}{c}\mathrm{X} 3= \\
\text { EBIT/ } \\
\text { TA }\end{array}$ & $\begin{array}{c}0,00 \\
52\end{array}$ & $\begin{array}{c}0,00 \\
56\end{array}$ & $\begin{array}{c}0,00 \\
53\end{array}$ & & $\begin{array}{c}0,01 \\
61\end{array}$ \\
\hline $\begin{array}{c}X 4= \\
B E / B \\
V D\end{array}$ & $\begin{array}{c}0,56 \\
80\end{array}$ & $\begin{array}{c}0,56 \\
90\end{array}$ & $\begin{array}{c}0,54 \\
05\end{array}$ & $\begin{array}{c}0,55 \\
52\end{array}$ & $\begin{array}{c}0,48 \\
52\end{array}$ \\
\hline $\begin{array}{c}6,56 \mathrm{X} \\
1 \\
\end{array}$ & $\begin{array}{c}0,88 \\
95 \\
\end{array}$ & $\begin{array}{c}1,13 \\
61\end{array}$ & $\begin{array}{c}1,13 \\
31 \\
\end{array}$ & $\begin{array}{c}0,81 \\
43 \\
\end{array}$ & $\begin{array}{c}0,85 \\
00 \\
\end{array}$ \\
\hline $\begin{array}{c}3,26 \mathrm{X} \\
2 \\
\end{array}$ & $\begin{array}{c}0,15 \\
02 \\
\end{array}$ & $\begin{array}{c}0,14 \\
75 \\
\end{array}$ & $\begin{array}{c}0,14 \\
58 \\
\end{array}$ & $\begin{array}{c}0,15 \\
04 \\
\end{array}$ & $\begin{array}{c}0,16 \\
87 \\
\end{array}$ \\
\hline $\begin{array}{c}6,72 X \\
3\end{array}$ & $\begin{array}{c}0,03 \\
53\end{array}$ & $\begin{array}{c}0,03 \\
77\end{array}$ & $\begin{array}{c}0,03 \\
59\end{array}$ & $\begin{array}{c}0,05 \\
73\end{array}$ & $\begin{array}{c}0,10 \\
82\end{array}$ \\
\hline $\begin{array}{c}1,05 X \\
4\end{array}$ & $\begin{array}{c}0,59 \\
64\end{array}$ & $\begin{array}{c}0,59 \\
75\end{array}$ & $\begin{array}{c}0,56 \\
75\end{array}$ & $\begin{array}{c}0,58 \\
30\end{array}$ & $\begin{array}{c}0,50 \\
95\end{array}$ \\
\hline $\begin{array}{c}\text { Z- } \\
\text { score }\end{array}$ & $\begin{array}{c}1,67 \\
14\end{array}$ & $\begin{array}{c}1,91 \\
90\end{array}$ & $\begin{array}{c}1,88 \\
24\end{array}$ & $\begin{array}{c}1,60 \\
52\end{array}$ & $\begin{array}{c}1,63 \\
66\end{array}$ \\
\hline
\end{tabular}

\section{Prediction Results of the Modified}

\section{Altman Z- score Method}

From the results of the analysis of the three companies sampled in 2015-2019, companies can be classified according to the cut-off point so that they can be categorized as healthy, gray area, and bankrupt companies. To make it easier to understand the results of the analysis, it can be explained by using the following table.

Table 4.4

Prediction Results Using Modified

Altman Z- score Method

\begin{tabular}{|c|c|c|c|c|c|}
\hline \multicolumn{6}{|c|}{ Altman Z- score Method } \\
\hline $\begin{array}{l}\text { Name } \\
\text { of Bank }\end{array}$ & 2015 & 2016 & 2017 & 2018 & $2019 \begin{array}{l}31,543,384 \text { (presented in million } \\
\text { rupiah), experienced an increase }\end{array}$ \\
\hline $\begin{array}{l}\text { Bank } \\
\text { BRIsyari } \\
\text { ah Inc }\end{array}$ & $\begin{array}{c}2,453 \\
3 \\
\text { Grey } \\
\text { area } \\
\end{array}$ & $\begin{array}{c}2,6114 \\
\text { Health } \\
y\end{array}$ & $\begin{array}{c}2,8715 \\
\text { Healthy }\end{array}$ & $\begin{array}{l}3,2181 \\
\text { Health } \\
y\end{array}$ & $\begin{array}{l}\text { again in } 2018 \text { of Rp. } 37,915,084 \\
2,818 \text { (presented in million rupiah), } \\
\text { Healththen in the year of } 2019 \text { total } \\
\text { assets of BRIsvariah Inc has }\end{array}$ \\
\hline $\begin{array}{l}\text { Bank } \\
\text { BTPN } \\
\text { Syariah } \\
\text { Inc }\end{array}$ & $\begin{array}{l}3,220 \\
7 \\
\text { Healt } \\
\text { hy }\end{array}$ & $\begin{array}{l}3,5885 \\
\text { Health } \\
y\end{array}$ & $\begin{array}{c}4,2789 \\
\text { Healthy }\end{array}$ & $\begin{array}{l}5,6796 \\
\text { Health } \\
y\end{array}$ & $\begin{array}{l}\text { 6,9443 } 3 \text { millions of rupiah). Even though } \\
\text { Healthy } \\
\text { the company experienced }\end{array}$ \\
\hline
\end{tabular}
financial distress only in 2015, then the following years the

Source: Processed Data

\section{Discussion}

1. Bank BRI syariah Inc

The results of the Altman z-score analysis show that BRIsyariah Inc stated that the company's financial condition in 2015 was in the gray area position or it could be said that the company was in financial distress, but in 2016-2019 it tried to improve the company's performance. It can be seen from the results of the $\mathrm{z}$ - score which was increasing every year and away from the value of financial distress. In addition, it can also be seen from the company's total assets which increased every year, in 2015 the total assets owned by the company amounted to IDR 24,230,247 (presented in millions of rupiah), in the following year, 2016, total assets increased by IDR 27,687.188 (presented in million rupiah), the following year, 2017 experienced an increase of Rp. $31,543,384$ (presented in million again in 2018 of Rp. 37,915,084 rupiah), assets of BRIsyariah Inc has 6,9443 reached 43,123,488 (presented in hy

then the following years the

\begin{tabular}{|c|c|c|c|c|c|}
\hline Bank \\
$\begin{array}{c}\text { Mandiri } \\
\text { Syariah } \\
\text { Inc }\end{array}$ & $\begin{array}{c}1,671 \\
\text { Grey } \\
\text { area }\end{array}$ & $\begin{array}{c}1,9190 \\
\text { Grey } \\
\text { area }\end{array}$ & $\begin{array}{c}1,8824 \\
\text { Grey } \\
\text { area }\end{array}$ & $\begin{array}{c}1,6052 \\
\text { Grey } \\
\text { area }\end{array}$ & $\begin{array}{c}1,6366 \\
\text { Grey } \\
\text { area }\end{array}$ \\
\hline
\end{tabular}


company was in a healthy condition. It is possible for the company to experience financial distress again. Therefore the company must remain careful and still maintain the company's condition both from an operational perspective and from a company financial perspective.

2. Bank BTPN Syariah Inc

The results of the Altman z- score analysis show that Bank BTPN Syariah Inc stated that the company's financial condition in 2015-2019 was in a healthy company condition. It means that that at that distance the company did not experience financial distress, it can be seen from the $z$ - score that exceeded the value of $2.6\left(Z^{\prime \prime}>2.6\right)$ each year. It can also be seen that the total debt was increasing every year, from Rp. 9,883,107 (presented in millions of rupiah) in 2015, up by Rp. 11,232,797 (presented in millions of rupiah) in 2016, again experiencing an increase in 2017, which was Rp. $13,531,435$ (presented in million rupiah), experienced an increase again of Rp. 14,477,262 (presented in million rupiah) in 2017, and again increased in 2019, Rp. 19,052,303 (presented in millions rupiah). It shows a company that continues to improve its company performance, so that the company can stay away from the possibility of experiencing bankruptcy. But that does not mean the company will not experience financial distress, therefore the company still has to be careful so that the company's performance continues to increase and the possibility of bankruptcy will not occur.

3. Bank Mandiri Syariah Inc The results of the Altman z- score analysis show that Bank Mandiri Syariah Inc stated that the company's financial condition in 2015-2019 experienced financial distress or it can be said that the company was in a gray area position. This is in accordance with the $\mathrm{z}$ - score results with a value of 1.1-2.6 $\left(1.1<Z^{\prime \prime}<2.6\right)$. It shows that the company had not been able to improve its performance so that the company had not been able to get out of financial distress. If the financial statements, the increase in total assets owned by the company did not seem to have a good enough impact on improving the condition of the company every year. It is also seen in the company's working capital, which experienced fluctuation, in 2015 amounting to Rp. 9,542,102 (presented in millions of rupiah), an increase in 2016, that is Rp. 13,653,366 (presented in millions of rupiah), experiencing an increase again. in 2017 amounting to Rp. $15,190,642$, decreased in 2018 
amounting to Rp. 12,208,208 (presented in million rupiah), until finally rising again in 2019 to Rp. $14,550,400$ (presented in millions of rupiah). The ups and downs of the company's working capital may be a factor in the occurrence of financial distress in the company. With these conditions, the company should immediately improve the company's performance. If the company continues to be in financial distress, it is possible that the company will experience a more severe condition that is bankruptcy.

\section{CONCLUSION}

It is known from the analysis results above that at Bank BRI
Syariah Inc, the company experienced financial distress in 2015, in the following years the company experienced improvements so that in 2016-2019, the company was classified as healthy. Meanwhile, Bank BTPN Syariah Inc, the condition of the company in 2015-2019 was considered healthy, which means that during that time the company did not experience financial distress. As for Bank Syariah MandiriInc, in 2015-2019 the company was in a gray area position or the company experienced financial distress, at that distance the company had not managed to get out of the gray area position.

\section{REFERENCES}

Ali, Salman Syed. Financial distress and Bank Failure: Lessons from Closure of Ihlas Finans in Turkey. SSRN Scholarly Paper. Rochester, NY: Social Science Research Network, January 1, 2007. Accessed August 25, 2020. https:/ / papers.ssrn.com/abstract $=3161383$.

Altman, Edward I., MałgorzataI wanicz-Drozdowska, Erkki K. Laitinen, and ArtoSuvas. "Financial distress Prediction in an International Context: A Review and Empirical Analysis of Altman's Z-Score Model." Journal of International Financial Management \& Accounting 28, no. 2 (2017): 131-171.

Andriawan, Nur Fadli, and Dantje Salean. "Analisis Metode Altman Z-Score Sebagai Alat Prediksi Kebangkrutan Dan Pengaruhnya Terhadap Harga Saham Pada Perusahaan Farmasi Yang Terdaftar Di Bursa Efek Indonesia." JEA17: Jurnal Ekonomi Akuntansi 1, no. 01 (April 8, 2016). Accessed October 1, 2020. http://jurnal.untag-sby.ac.id/index.php/JEA17/article/view/650.

Anshori, Abdul Ghofur. Perbankan Syariah Di Indonesia. Yogyakarta: UGM Press, 2018.

Bod'a, Martin, and Vladimír Úradníček. “The Portability of Altman's Z-Score Model to Predicting Corporate Financial distress of Slovak Companies." Technological and Economic Development of Economy 22, no. 4 (July 3, 2016): 532-553. 
Brealey, Myers, and Marcus. Dasar-Dasar ManajemenKeuangan Perusahaan. 5th ed. Jakarta: Erlangga, 2006.

Fahmi, Irham. Manajemen Keuangan Perusahaan Dan Pasar Modal. Jakarta: Mitra Wacana Media, 2014.

Holmes, George M., Brystana G. Kaufman, and George H. Pink. "Predicting Financial distress and Closure in Rural Hospitals." The Journal of Rural Health 33, no. 3 (2017): 239-249.

Ilham, Muhammad. "Analisis Potensi Financial distress Pada Bank Syariah Di Indonesia Pasca Krisis Global Periode Tahun 2010 - 2016" (May 11, 2018). Accessed August 25, 2020. https://dspace.uii.ac.id/handle/123456789/7872.

Kariyoto. Kariyoto, ManajemenKeuangan: Konsep Dan Implementasi. Malang: Universitas Brawijaya Press, 2018.

Meiliawati, Anggi, and IsharijadiIsharijadi. "AnalisisPerbandingan Model Springate Dan Altman Z Score Terhadap Potensi Financial distress (StudiKasus Pada Perusahaan Sektor Kosmetik Yang Terdaftar Di Bursa Efek Indonesia)." Assets: JurnalAkuntansi dan Pendidikan 5, no. 1 (April 25, 2017): 15-24.

Munawir, S. Analisis Informasi Keuangan. 1st ed. Yogyakarta: Liberty Yogyakarta, 2002.

Natariasari, Riska, and Nofiandre. "Analisis Prediksi Kebangkrutan Menggunakan Model Z-Score Altman pada Perusahaan Perbankan Yang Terdaftar di Bursa Efek Indonesia Periode 2008-2010." Jurnal Sosial Ekonomi Pembangunan 10 (2013): 23.

Pratama, Rendra. “Analisis Pengaruh Rasio Keuangan Untuk Memprediksi Kondisi Financial distress Bank Umum Syariah Menggunakan Model Logit Di Indonesia." Undergraduate, STIE PERBANAS SURABAYA, 2016. Accessed August 15, 2020. http:/ / eprints.perbanas.ac.id/528/.

Radoni, Ahmad, and Herni Ali. Manajemen Keuangan Modern. Jakarta: Mitra Wacana Media, 2014.

Riswan, Riswan, and Yolanda Fatrecia Kesuma. “Analisis Laporan Keuangan Sebagai Dasar Dalam Penilaian Kinerja Keuangan PT. Budi Satria Wahana Motor." Jurnal Akuntansi dan Keuangan 5, no. 1 (March 31, 2014). Accessed August 13, 2020. http://jurnal.ubl.ac.id/index.php/jak/article/view/449.

Shidiq, Imaduddin, and Buddi Wibowo. "PrediksiFinancial distress Bank Umum di Indonesia: Analisis Diskriminan dan Regresi Logistik." ESENSI :Jurnal Bisnis dan Manajemen 7, no. 1 (February 4, 2017): 27-40.

Suartini, Sri, and dkk. Analisis Laporan Keuangan Bagi Mahasiswa Dan Praktikan. Jakarta: Mitra Wacana Media, 2017.

Sudana, I Made. Manajemen Keuangan Teori Dan Praktik. Surabaya: Airlangga University Press, 2009.

Tarigan, Josua, SwenjiadiYenewan, and Grace Natalia. Merger Dan Akuisisi: Perspektif Strategis Dan Kondisi Indonesia. Yogyakarta: Ekuilibria, 2017. 